\title{
PENGARUH PENERAPAN MANAJEMEN KINERJA TERHADAP PRODUKTIVITAS PEGAWAI
}

\author{
*Andita Niken Anggraeni ${ }^{1)}$, Yaqub Cikusin ${ }^{2)}$, Hayat ${ }^{3)}$ \\ 1), 2), 3) Jurusan Administrasi Negara, Fakultas Ilmu Administrasi, Universitas Islam \\ Malang, Indonesia \\ *Email Korespondensi : andita.nikena@gmail.com
}

\begin{abstract}
Abstrak
Bagian Pemerintah Sekretariat Daerah Kota Batu merupakan instansi yang bersifat birokrat yang berada dibawah tanggung jawab Sekretariat Daerah yang terletak di Balaikota "Among Tani" Block Office Gedung A Lantai 3 Jl. Panglima Sudirman No. 507 Batu 65313. Penelitian ini bertujuan untuk mengetahui pengaruh penerapan Manajemen Kinerja (penetapan target kinerja, pelaksanaan kinerja, penilaian kinerja, dan evaluasi kinerja) terhadap produktivitas pegawai di Bagian Pemerintah Sekretariat Daerah Kota Batu. Metode penelitian yang ini menggunakan metode kuantitatif. Metode pengumpulan data yakni penyebaran kuisioner dan dokumentasi sebagai pelengkap data. Teknik analisis yang digunakan yakni analisis regresi linier berganda dengan program SPSS 25. Hasil penelitian ini menunjukkan bahwa secara parsial penetapan target kinerja berpengaruh signifikan terhadap produktivitas pegawai. Pelaksanaan kinerja secara parsial tidak berpengaruh signifikan terhadap produktivitas pegawai. Penilaian kinerja secara parsial berpengaruh signifikan terhadap produktivitas pegawai. Selanjutnya, evaluasi kinerja secara parsial berpengaruh signifikan terhadap produktivitas pegawai. Sedangkan secara simultan penerapan manajemen kinerja (penetapan target kinerja, pelaksanaan kinerja, penilaian kinerja, dan evaluasi kinerja) berpengaruh signifikan terhadap produktivitas pegawai.
\end{abstract}

Kata Kunci: Manajemen Sumber Daya Manusia (MSDM); Manajemen Kinerja; Produktivitas Pegawai.

\begin{abstract}
Government Section the regional Secretariat of Bstu City is a bureaucratic agency under the responsibility of the Regional Secretariat which is located at City Hall "Among Tani" Block Office Building a $3^{\text {rd }}$ Floor at Jl. Panglima Sudirman No. 507 Batu 65313. This study aims to determine the effect of the implementation of Performance Management (setting performance targets, performance implementation, performance appraisal, and performance evaluation) on employee productivity in the Government Section of the Regional Secretariat of Batu City. This research method uses quantitative methods. Data collection methods are questionnaires and documentation to complement the data. The analysis technique used is multiple linear regression analysis with the SPSS 25 program. The results of this study indicate that partially the setting of performance targets has a significant effect on employee productivity. Implementation of performance partially
\end{abstract}


does not have a significant effect on employee productivity. Performance appraisal partially has a significant effect on employee productivity. Furthermore, performance evaluation partially has a significant effect on employee productivity. Meanwhile, the simultaneous implementation of performance management (setting performance targets, implementing performance, performance appraisal, and performance evaluation) has a significant effect on employee productivity.

Keywords: Human Resource Management; Performance Management, Employee Productivity.

\section{PENDAHULUAN}

Menurut Schwartz (Nursam, 2017) memandang manajemen kinerja sebagai gaya manajemen yang didasarkan pada komunikasi terbuka antara manajer dan karyawan yang menyangkut penetapan tujuan, memberikan umpan balik dari manajer kepada karyawan maupun sebaliknya, demikian pula penilaian kinerja.

Manajemen kinerja pada instansi pemerintah juga diatur dalam Peraturan Pemerintah Nomor 30 Tahun 2019 tentang Penilaian Kinerja Pegawai Negeri Sipil. Salah satu pertimbangan pembentukan peraturan pemerintah ini didasarkan pada Undang-Undang Nomor 5 Tahun 2014 tentang Aparatur Sipil negara. Peraturan Pemerintah tersebut mengatur tentang sistem manajemen kinerja. Didalamnya dijelaskan sistem manajemen kinerja ASN meliputi 5 tahapan, diantaranya perencanaan kinerja ; pelaksanaan, pemantauan dan pembinaan kinerja; penilaian kinerja; tindak lanjut; dan sistem informasi kinerja PNS. Peraturan pemerintah tersebut menjadi dasar bagi instansi pemerintah khususnya Bagian Pemerintahan Sekretariat Daerah Kota Batu dalam melaksanakan setiap kegiatan.

Tugas dan tanggung jawab Bagian Pemerintahan Sekretariat Daerah Kota Batu diatur dalam Perwali Kota Batu Nomor 105 Tahun 2020 (Timur \& Batu, 2018) tentang Kedudukan, Susunan Organisasi, Uraian Tugas dan Fungsi, Serta Tata Kerja Sekertariat Daerah Pasal 11 dan 12. Dari kedua pasal diatas, melekatlah tanggung jawab Bagian Administrasi Pemerintahan dan Otonomi Daerah dalam menjalankan tugasnya guna membantu pejabat pembina bagian dalam melaksanakan manajemen kinerja daerah sesuai asas umum pemerintahan yang baik yakni menyelenggarakan pembangunan dan pelayanan yang berdaya guna, bertanggung jawab serta bebas dari Korupsi, Kolusi, dan Nepotisme (KKN). 
Berdasarkan hasil pengamatan sementara dilapangan diketahui bahwa terdapat empat tahapan manajemen kinerja di Bagian Pemerintahan Sekretariat Daerah Kota Batu yakni meliputi, diantaranya penetapan target kinerja, pelaksanaan kinerja, penilaian kinerja dan evaluasi (tindak lanjut) kinerja.

Namun pada penerapan sistem manejemen di Indonesia, Kementerin PAN-RB pada hasil evaluasi penerapan manajemen kinerja mengungkapkan bahwa terdapat masalah terkait ketidakmampuan instansi pemerintah untuk (a) menetapkan tujuan dan sasaran strategi yang berorientasi pada hasil, (b) menetapkan ukuran keberhasilan yang menggambarkan derajat tercapainya tujuan (c) menetapkan aktivitas/program yang berdampak bagi pencapainya tujuan /sasaran (d) menetapkan alokasi anggaran program/kegiatan yang selaras dengan tujuan. (Salsabila Firdausy dan Ummu Nur Hanifah, 2018)

Hal serupa juga dijelaskan oleh Sedarmayanti dalam (Dunggio, 2013) ada beberapa faktor yang mempengaruhi produktivitas kerja pegawai, salah satunya yakni manajemen. Manajemen merupakan suatu proses yang berkaitan dengan perencanaan , pengorganisasian, pergerakan, pengawasan, dan penilaian. Manajemen juga merupakan teori dasar dari MSDM dan manajemen kinerja. Pada siklus manajemen kinerja, terdapat beberapa tahapan, salah satunya yakni penilaian kinerja. Dijelaskan oleh Hayat , (2014) bahwa pada tahapan penilaian kinerja terdapat sistem karier yang dapat meningkatkan kualitas SDM aparatur dan berdampak positif pada peningkatan kualitas SDM menjadi lebih baik. Kualitas SDM yang baik akan mempengaruhi hasil kinerja dan dapat meningkatkan produktivitas kinerja pegawai. Dari beberapa pendapat tersebut dapat disimpulkan bahwa penerapan manajemen kinerja pada suatu instansi dapat mempengaruhi penetapan kinerja merupakan tahap awal yang akan mempengaruhi pelaksanaan kinerja, penilaian kinerja hingga evaluasi kinerja.

Berdasarkan uraian diatas, maka penulis tertarik untuk mengambil penelitian dengan judul "Pengaruh Penerapan Sistem Manajemen Kinerja Terhadap Produktivitas Pegawai Di Bagian Pemerintahan Sekretariat Daerah Kota Batu". 
1. Apakah Penerapan Manajemen Kinerja (Penetapan Target Kinerja, Pelaksanaan Kinerja , Penilaian Kinerja, Evaluasi Kinerja) Berpengaruh Secara Parsial Terhadap Produktivitas Pegawai Di Bagian Pemerintahan Sekretariat Daerah Kota Batu?

2. Apakah Penerapan Manajemen Kinerja (Penetapan Target Kinerja, Pelaksanaan Kinerja , Penilaian Kinerja, Evaluasi Kinerja) Berpengaruh Simultan Terhadap Produktivitas Pegawai Di Bagian Pemerintahan Sekretariat Daerah Kota Batu

\section{TINJAUAN PUSTAKA}

\section{Manajemen Sumber Daya Manusia}

Menurut Barthos, (2012) manajemen sumber daya manusia merupakan hal-hal yang berkaitan dengan pembinaan, penggunaan, dan perlindungan sumber daya manusia baik yang berada dalam hubungan kerja maupun usaha sendiri. Menurut Marwansyah dalam (Yusuf, 2015)manajemen sumber daya manusia dapat diartikan sebagai pendayagunaan sumber daya manusia didalam suatu organisasi, yang dilaksanakan sesuai fungsi-fungsi perencanaan sumber daya manusia, perencanaan dan pengembangan karir, pemberian kompensasi kesejahteraan, keselamatan dan kesehatan kerja, dan hubungan industrial.

\section{Manajemen Kinerja}

Menurut Schwartz dalam Nursam, (2017) memandang manajemen kinerja sebagai gaya manajemen yang didasarkan pada komunikasi terbuka antara manajer dan karyawan yang menyangkut penetapan tujuan, memberikan umpan balik dari manajer kepada karyawan maupun sebaliknya, demikian pula penilaian kinerja. Hayat, (2018)menjelaskan manajemen kinerja merupakan pendayagunaan sumber daya dan informasi dalam hal ini untuk pencapaian tujuan organisasi melalui proses yang jelas dan terukur.

Menurut Blanchard dan Garry Ridge yang dikutip oleh (Wibowo, 2016)) siklus manajemen kinerja terdiri dari empat tahap, diantaranya: Pertama, perencanaan kinerja, merupakan bagian terpenting dalam proses manajemen kinerja. Menurut Bacal dalam Wibowo, (2016) perencanaan merupakan proses dimana pegawai dan atasan bersama merencanakan apa yang harus dilakukan pekerja dalam setahun mendatang, mendefinisikan bagaimana kinerja harus diukur, mengidentifikasi dan merencanakan, mengatasi hambatan dan mendapatkan saling pengertian tentang pekerjaan. Kedua, 
pelaksanaan kinerja menurut Wibowo, (2016) pada tahap ini manajer atau pimpinan mengamati dan memonitor kinerja bawahannya, memuji kemampuan dan mengarahkan apabila diperlukan. Ketiga, penilaian kinerja menurut Bacal dalam (Wibowo, 2016) penilaian kinerja (performance appraisal) adalah suatu proses yang diselenggarakan oleh perusahaan untuk mengevaluasi atau melakukan penilaian kinerja individu setiap pegawainya. Keempat, evaluasi kinerja Wibowo, (2016)menjelaskan evaluasi kinerja merupakan proses mengevaluasi pegawai dari berbagai dimensi yang berkaitan dengan pekerjaan.

\section{Produktivitas}

Menurut Sinungan, (2013)produktivitas kerja merupakan jumlah output yang dihasilkan seseorang secara utuh dalam satuan waktu kerja yang dilakukan yakni meliputi kegiatan yang efektif dalam mencapai hasil yang bersumber dari input dan menggunakan bahan yang efisien. Menurut Yusuf, (2015)Produktivitas kerja merupakan perbandingan antara hasil yang dicapai dengan pasar tenaga kerja persatuan waktu dan sebagai tolak ukur jika ekspansi dan aktivitas dari sikap sumber yang digunakan selama produktivitas berlangsung dengan membandingkan jumlah yang dihasilkan dengan setiap sumber daya yang digunakan.

Adapun faktor-faktor yang mempengaruhi produktivitas pegawai menurut Ravianto, (2014) diantaranya: (a) Motivasi, (b) keterampilan, (c) Pendidikan, (d) pengawasan, (e) Lingkungan, (f) Manajemen Sumber Daya Manusia/MSDM. 


\section{Hipotesis}

Berdasarkan uraian diatas, maka hipotesis yang diajukan dalam penelitian ini adalah sebagai berikut:

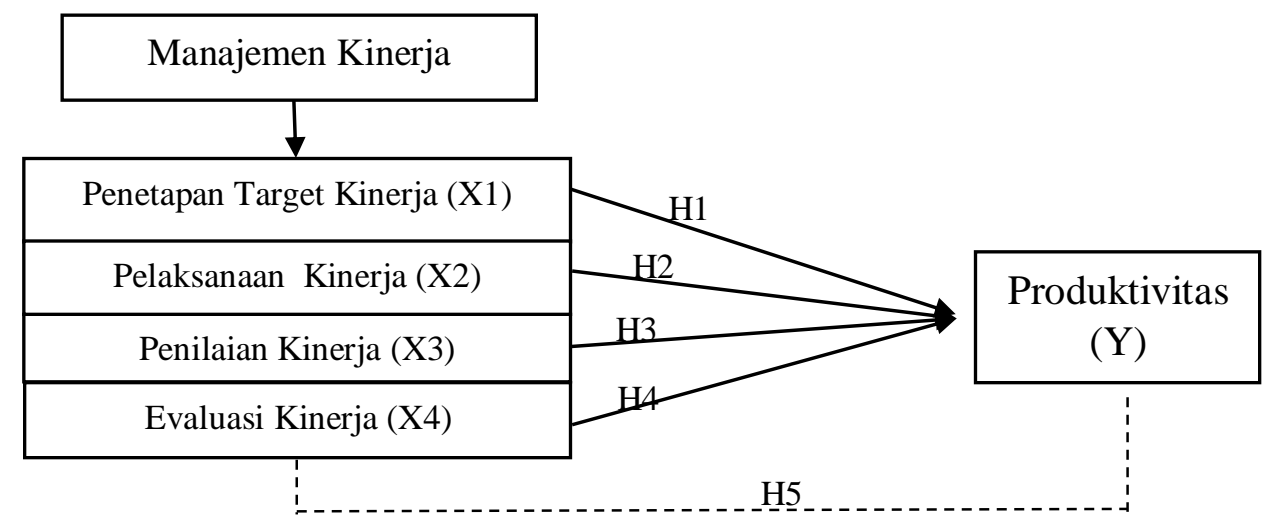

\section{Gambar 1. Model Penelitian}

Keterangan :

- hubungan secara parsial

- : hubungan secara simultan

Dari kerangka hipotesis diatas maka rumusan hipotesis adalah:

a. Diduga penetapan target kinerja berpengaruh signifikan dan positif terhadap produktifitas pegawai.

b. Diduga pelaksanaan kinerja berpengaruh signifikan dan positif terhadap produktifitas pegawai.

c. Diduga penilaian kinerja berpengaruh signifikan dan positif terhadap produktifitas pegawai.

d. Diduga evaluasi kinerja berpengaruh signifikan dan positif terhadap produktifitas pegawai.

e. Diduga manajemen kinerja berpengaruh signifikan dan positif terhadap produktifitas pegawai secara simultan. 


\section{METODE PENELITIAN}

\section{Jenis Penelitian}

Penelitian ini menjelaskan tentang Pengaruh penerapan manajemen kinerja (penetapan target kinerja, pelaksanaan kinerja, penilaian kinerja, dan evaluasi kinerja) terhadap produktivitas pegawai di Bagian Pemerintahan Sekretariat Daerah Kota Batu. Dalam penelitian ini metode ysng digunakan adalah metode penelitian kuantitatif.

\section{Variabel dan Pengukuran}

Menurut Sugiyono, (2016) variabel merupakan suatu atribut atau sifat atau nilai dari orang, objek atau kegiatan yang memiliki variasi tertentu yang ditetapkan oleh peneliti untuk dipelajari dan ditarik kesimpulan. Adapun pada penelitian ini dimana variabel dibagi menjadi dua, yakni:

1. Variabel bebas atau X (Independent Variable) yaitu variabel prediktor. Adapun variabel bebas pada penelitian ini adalah sistem manajemen kinerja yang meliputi penetapan target kinerja (X1), pelaksanaan kinerja (X2), penilaian kinerja (X3) dan evaluasi kinerja (X4).

2. Variabel terikat atau Y (Dependent Variable) atau disebut variabel kriteria. Variabel terikat dalam penelitian ini adalah produktivitas pegawai (Y).

Dalam penelitian ini untuk mengukur pengaruh variabel $\mathrm{X}$ terhadap variabel $\mathrm{Y}$, peneliti menggunakan skala rikert sebagai alat ukur.

\section{Populasi dan Sampel}

Sampel merupakan bagian dari populasi yang dapat diwakili karakteristik populasi tersebut. Menurut Sugiyono, (2016) sampel adalah bagian dari jumlah dan karakter yang dimiliki populasi. Jenis sampel yang digunakan peneliti yakni sampel jenuh karena jumlah populasi yang diteliti tidak lebih dari 30 responden. Untuk di Bagian Pemerintahan Sekretariat Daerah Kota Batu jumlah sampel yang digunakan berjumlah 22 responden.

\section{Lokasi Penelitian}

Penelitian ini dilakukan di Bagian Pemerintahan Sekretariat Daerah Kota Batu, terletak di Balaikota "Among Tani" Block Office Gedung A Lantai 3 Jl. Panglima Sudirman No. 507 Batu 65313.

\section{Teknik Pengumpulan Data}


Teknik pengumpulan data merupakan langkah paling strategis dalam penelitian, karena tujuan utama dari penelitian adalah mendapatkan data Sugiyono, (2016). Untuk mengumpulkan data penelitian, peneliti menggunakan metode kuisioner (angket) Menurut Sugiyono, (2016) kuisioner merupakan teknik pengumpulan data yang dilaksanakan dengan cara memberi beberapa pertanyaan atau pernyataan kepada responden untuk dijawab. Teknik angket digunakan untuk mengetahui sejauh mana pengaruh penerapan manajemen kinerja terhadap produktivitas pegawai.

\section{Metode Analisis Data}

\section{Uji Reliabilitas}

Menurut Sugiyono, (2016) uji reabilitas dilakukan untuk mengetahui seberapa jauh hasil pengukuran tetap konsisten apabila dilakukan pengukuran dua kali atau lebih terhadap gejala yang sama dengan alat ukur yang sama.

\section{Uji Asumsi Klasik}

\section{a. Uji Normalitas}

Menurut Ghozali, (2018) Uji normalitas digunakan untuk mengetahui dan menguji apakah dalam model regresi data terdistribusi dengan normal atau tidak. Model regresi yang baik harus mempunyai data yang terdistribusi dengan normal. Untuk menguji normalitas dalam penelitian ini menggunakan analisis grafik histogram dan analisis grafik normal p-plot yang dilakukan dengan membandingkan data observasi dan distribusi yang mendekati distribusi normal.

\section{b. Uji Heteroskedastisitas}

Menurut Ghozali, (2018) uji heteroskedastisitas bertujuan untuk menguji apakah dalam model regresi terjadi ketidaksamaan variance dari residual satu pengamat ke pengamat yang lain. Cara paling umum untuk mengetahui suatu data terjadi heteroskedastisitas yakni dengan menggunakan metode scatter plot dan uji glejser.

\section{c. Uji Multikolinieritas}

Menurut Ghozali, (2018) Multikolinieritas adalah korelasi tinggi yang terjadi antara variabel bebas lainnya. Adapun cara yang dapat digunakan untuk 
mendeteksi ada atau tidaknya multikolinieritas dengan menggunakan nilai tolerance dan varian inflation factor (VIF).

\section{Uji Hipotesis}

\section{a. Analisis Regresi Berganda}

Analisis regresi berganda mempunyai lebih dari satu variabel independen yang dapat mempengaruhi variabel dependen. Untuk menganaisis regresi berganda diukur menggunakan Koefisien Determinasi (R2), Uji statistic F, dan Uji statistic t.

Model persamaan dari penelitian adalah :

$Y=a+b_{1} X_{1}+b_{2} X_{2}+b_{3} X_{3}+b_{4} X_{4}+e$

Dimana :

$\mathrm{Y}=$ produktivitas

$\mathrm{A}=$ konstanta

X1= Penetapan Target Kinerja

X2= Pelaksanaan Kinerja

X3= Penilaian Kinerja

X4= Evaluasi Kinerja

$\mathrm{e}=$ eror

dalam analisis regresi berganda dilakukan melalui:

\section{1) Uji Koefisien Determinasi (R Kuadrat)}

Menurut Ghozali, (2018) koefisien determinasi adalah koefisien yang digunakan untuk mengukur seberapa jauh kemampuan model dalam menerangkan variasi variabel dependen (variabel terikat). Nilai koefisien deteminasi adalah $0-1$.

\section{2) Uji Signifikan Simultan (Uji Statistik F)}

Pengujian hipotesis ini dimaksudkan untuk mengetahui sebuah taksiran parameter secara bersama-sama, yang artinya seberapa besar pengaruh dari variabel-variabel independen terhadap variabel dependen secara bersama Ghozali, (2018). Kriteria pengambilan keputusan sebagai berikut:

a. Bila F Hitung $\geq \mathrm{F}$ table atau sig $\leq 0,05$ maka HO ditolak. 
b. Bila F Hitung < F Tabel atau sig > 0,05 maka HO diterima.

\section{3) Uji Parsial (uji t)}

Menurut Ghozali, (2018)uji statistic t juga disebut dengan uji parsial, pengujian ini bertujuan untuk menguji secara individu dengan uji hipotesis terpisah bahwa setiap koefisien regresi sama dengan nol. Uji statistic t pada dasarnya menunjukkan seberapa berpengaruh satu variabel penjelasan atau independen secara individual dalam menjelaskan. Kriteria pengambilak keputusan sebagai berikut :

a. Jika $t$ hitung $<\mathrm{t}$ table atau $-\mathrm{t}$ hitung $>-\mathrm{t}$ table atau sig $>0,05(5 \%)$ maka HO diterima.

b. Jika $t$ hitung $\geq \mathrm{t}$ table atau $-\mathrm{t}$ hitung $\geq-\mathrm{t}$ table atau $\operatorname{sig} \leq 0,05(5 \%)$ maka HO ditolak.

\section{HASIL DAN PEMBAHASAN}

\section{Uji Reliabilitas}

Tabel 4 Hasil Uji Reliabilitas

\begin{tabular}{|c|c|c|c|c|}
\hline Variabel & Indicator & $\begin{array}{l}\text { Cronbach } \\
\text { alpha }\end{array}$ & $\begin{array}{l}\text { Nilai } \\
\text { signifikan }\end{array}$ & Reliable/tidak reliable \\
\hline Manajemen kinerja & Penetapan target kinerja & 0,941 & 0,60 & Reliable \\
\hline & Pelaksanaan kinerja & 0,940 & 0,60 & Reliable \\
\hline & Penilaian kinerja & 0,948 & 0,60 & Reliable \\
\hline & Evaluasi kinerja & 0,942 & 0,60 & reliable \\
\hline Produktivitas & & 0,941 & 0,60 & reliable \\
\hline
\end{tabular}

Sumber : Output SPSS diolah peneliti, 2021

Berdasarkan tabel uji realibilitas diatas, menunjukkan bahwa nilai dari Cronbach alpha lebih besar > dari nilai signifikan $(0,60)$, artinya variabel pada penelitian ini dapat dikatakan reliable. 


\section{Uji Asumsi Klasik}

\section{a. Uji Normalitas}

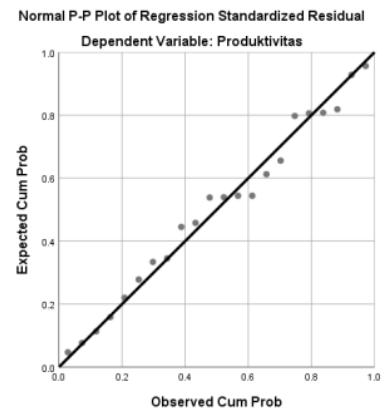

Gambar 1 Uji Normalitas Dengan Grafik Normality Probability Plot Sumber : Output SPSS diolah peneliti, 2021

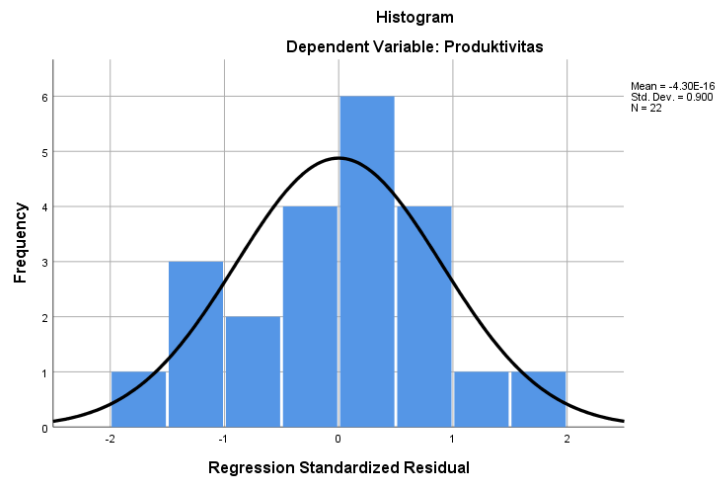

\section{Gambar 2 Grafik Histogram}

\section{Sumber : Output SPSS diolah peneliti, 2021}

Berdasarkan gambar grafik histogram norality grafik normality probability plot (gambar 1) dan grafik histogram (gambar 2) dapat disimpulkan bahwa grafik tersebut menunjukkan bahwa model dari regresi memenuhi asumsi normalitas. Pada gambar grafik histrogram normality (gambar 2) data menunjukkan terdistribusi normal terlihat dari bentuj lonceng yang simetris tidak condong ke kanan maupun ke kiri. Pada grafik normality probability plot (gambar 1) data menyebar di sekitar garis diagonal dan mengikuti arah garis diagonal tersebut, oleh karena itu dari kedua grafik tersebut dapat dikatakan memenuhi asumsi normalitas. 


\section{b. Uji heteroskedastisitas}

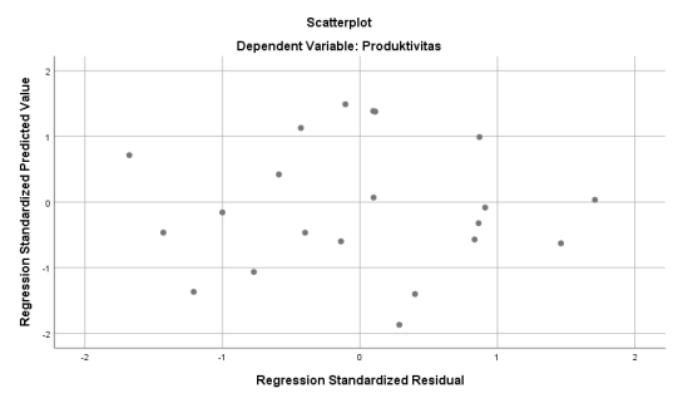

\section{Gambar 3 Hasil Uji Heteroskedastisitas Dengan Grafik Scatterplot}

\section{Sumber : Output SPSS diolah peneliti, 2021}

Berdasarkan gambar diatas hasil uj heteroskedastisitas dengan grafik scatterplot menunjukkan bahwa pada grafik tersebut tidak menunjukkan bahwa ada pola yang terbentuk dengan jelas. Selain itu, pada grafik menyebar diatas maupun dibawah angka dibawah 0 pada sumbu $\mathrm{Y}$, hal tersebut menunjukkan bahwa tidak terdapat gejala heteroskedas-tisitas.

\section{c. Uji multikolinieritas}

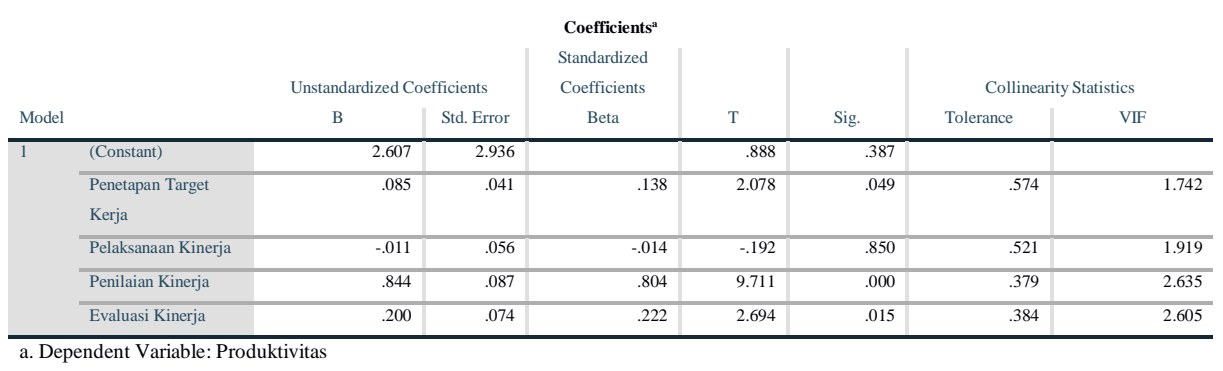

Tabel 2 Hasil Uji Multikolonieritas

\section{Sumber : Output SPSS diolah peneliti, 2021}

Berdasarkan hasil tabel di atas, hasil dari pengujian multikolinearitas mendapat tolerance value $>0,10$ dan VIF $<10$. Maka dapat disimpulkan bahwa variabel independen Dalam penelitian ini tidak memiliki korelasi sehingga dapat dikatakan tidak terjadi gejala multikolinearitas.

\section{Uji Hipotesis}

Untuk menguji hipotesis yang menyatakan diduga berpengaruh signifikan dan positif antara manajemen kinerja (penetapan target kinerja, pelaksanaan kinerja, penilaian kinerja, dan evaluasi kinerja ) terhadap produktivitas pegawai secara parsial. Pertama, 
hasil uji t penetapan target kinerja memiliki nilai tabel $(2,073)<\mathrm{t}$ hitung $(2,078)$ dengan nilai sig. 0,049 kurang dari $(<)$ 0,05. Sehingga terbukti penetapan target kinerja berpengaruh signifikan terhadap produktivitas pegawai. Kedua, hasil uji t pelaksanaan kinerja memiliki nilai tabel $(2,073)>t$ hitung $(0,192)$ dengan nilai sig. 0,850 lebih besar dari (>) 0,05. Sehingga terbukti pelaksanaan kinerja tidak berpengaruh signifikan terhadap produktivitas pegawai. Ketiga, Hasil uji t penilaian kinerja memiliki nilai tabel $(2,073)<$ t hitung $(9,711)$ dengan nilai sig. 0,00 kurang dari $(<)$ 0,05. Sehingga terbukti penilaian kinerja berpengaruh signifikan terhadap produktivitas pegawai. Keempat, hasil uji t evaluasi kinerja memiliki nilai tabel $(2,073)<\mathrm{t}$ hitung $(2,694)$ dengan nilai sig. 0,015 kurang dari $(<)$ 0,05. Sehingga terbukti evaluasi kinerja berpengaruh signifikan terhadap produktivitas pegawai.

\section{Pengaruh Penetapan Target Kinerja terhadap produktivitas pegawai di Bagian}

\section{Pemerintahan Sekretariat Daerah Kota Batu Secara Parsial}

Hasil penelitian menunjukkan bahwa secara parsial penetapan target kinerja berpengaruh terhadap produktivitas pegawai. Memiliki nilai signifikansi 0,049 kurang dari $(<)$ nilai signifikansi yang ditentukan yakni 0,05 . Dengan demikian penelitian ini menolak H01 dan menerima Ha1, dapat diartikan secara parsial Penetapan Target Kinerja berpengaruh signifikan terhadap produktivitas pegawai di Bagian Pemerintahan Sekretariat Daerah Kota Batu.

Hal ini menunjukkan semakin besar/ semakin matang proses penetapan target kinerja/perencanaan kinerja akan memberikan pengaruh pada peningkatan produktivitas pegawai. Selain itu berdasarkan hasil signifikan, Bagian Pemerintahan Sekretariat Daerah Kota Batu dapat menggunakan penetapan target kinerja atau perencanaan kinerja dalam meningkatkan produktivitas pegawai. Dengan meningkatnya produktivitas pegawai khususnya disektor publik, hal ini dapat menjadi jawaban bahwa pemerintah birokrat bekerja sesuai tanggung jawab dan tugasnya.

\section{Pengaruh Pelaksanaan Kinerja terhadap produktivitas pegawai di Bagian Pemerintahan Sekretariat Daerah Kota Batu Secara Parsial}

Hasil penelitian menunjukkan bahwa secara parsial pengaruh pelaksanaan kinerja terhadap produktivitas pegawai memiliki nilai signifikansi sebesar 0,850 lebih besar (>) 
dari nilai signifikan yang ditentukan yaitu 0,05. Dengan demikian, penelitian ini menerima H02 dan menolak Ha2, artinya secara parsial pelaksanaan kinerja tidak berpengaruh signifikan terhadap produktivitas pegawai di Bagian Pemerintahan Sekretariat Daerah Kota Batu.

Berdasarkan hasil yang tidak signifikan, hal ini tidak akan berpengaruh besar terhadap produktivitas pegawai. Karena produktivitas pegawai dipengaruhi oleh beberapa hal seperti yang diteliti pada penelitian ini maupun diluar penelitian.

\section{Pengaruh Penilaian Kinerja terhadap produktivitas pegawai di Bagian Pemerintahan Sekretariat Daerah Kota Batu Secara Parsial}

Hasil penelitian menunjukkan bahwa secara parsial penilaian kinerja berpengaruh terhadap produktivitas pegawai. Memiliki nilai signifikansi 0,00 kurang dari $(<)$ nilai signifikansi yang ditentukan yakni 0,05 . Dengan demikian penelitian ini menolak H03 dan menerima Ha3, dapat diartikan secara parsial penilaian kinerja berpengaruh signifikan terhadap produktivitas pegawai di Bagian Pemerintahan Sekretariat Daerah Kota Batu.

Hal ini menunjukkan semakin besar nilai dari penilaian kinerja pegawai akan memberikan pengaruh pada peningkatan produktivitas pegawai. Selain itu berdasarkan hasil signifikan, Bagian Pemerintahan Sekretariat Daerah Kota Batu dapat menggunakan penilaian kinerja atau dalam meningkatkan produktivitas pegawai. Penilaian kinerja menjadi salah satu pengaruh terhadap kenaikan pangkat maupun gaji di organisasi sektor publik. Maka dari itu setiap pegawai diharuskan meningkatkan kinerja dan produktivitas agar penilaian kinerja sesuai dengan apa yang dikerjakan dan diharapkan.

\section{Pengaruh Evaluasi Kinerja terhadap produktivitas pegawai di Bagian}

\section{Pemerintahan Sekretariat Daerah Kota Batu Secara Parsial}

Hasil penelitian menunjukkan bahwa secara parsial evaluasi kinerja berpengaruh terhadap produktivitas pegawai. Memiliki nilai signifikansi 0,015 kurang dari (<) nilai signifikansi yang ditentukan yakni 0,05. Dengan demikian penelitian ini menolak H04 dan menerima Ha4, dapat diartikan secara parsial evaluasi kinerja berpengaruh signifikan terhadap produktivitas pegawai di Bagian Pemerintahan Sekretariat Daerah Kota Batu.

Hal ini menunjukkan semakin besar nilai/proses evaluasi kinerja dilakukan oleh pimpinan maka semakin besar pula peningkatan produktivitas pegawai. Selain itu 
berdasarkan hasil signifikan, Bagian Pemerintahan Sekretariat Daerah Kota Batu dapat menggunakan evaluasi kinerja dalam meningkatkan produktivitas pegawai. Dengan meningkatnya produktivitas pegawai khususnya disektor publik, hal ini dapat menjadi jawaban bahwa pemerintah birokrat bekerja sesuai tanggung jawab dan tugasnya.

Pengaruh Manajemen Kinerja (Penetapan Target Kinerja, Pelaksanaan Kinerja, Penilaian Kinerja, Evaluasi Kinerja) terhadap produktivitas pegawai secara simultan

Berdasarkan hasil pengujian hipotesis yang menggunakan uji statistic $\mathrm{F}$, diduga bahwa variabel Penetapan Target Kinerja (X1), Pelaksanaan Kinerja (X2), Penilaian Kinerja (X3), dan Evaluasi Kinerja (X4) secara simultan berpengaruh signifikan secara bersamasama terhadap produktivitas (Y), karena F hitung sebesar 15,738 dengan nilai sig. sebesar 0,000. Dengan persamaan regresi linear Y = 0,085 X1-0,11 X2+0,844 X3+0,200 X4.

Hasil penelitian ini menyatakan bahwa Penetapan Target Kinerja, Pelaksanaan Kinerja, Penilaian Kinerja, dan Evaluasi Kinerja (Manajemen Kinerja) secara simultan berpengaruh signifikan terhadap produktivitas pegawai. Hal ini menunjukkan bahwa manajemen kinerja merupakan informasi utama yang diperhatikan oleh pimpinan dalam membuat keputusan. Keempat variabel tersebut membantu pimpinan untuk menerapkan manajemen SDM khususnya manajemen kinerja. Penerapan manajemen kinerja yang baik akan mendorong peningkatan produktivitas maupun kualitas yang berdampak pada berjalannya birokrasi dengan baik.

Hasil penelitian ini sesuai dengan teori yang dikemukakan oleh Sedarmayanti (dalam Dunggio, 2013)yang menyatakan bahwa factor yang mempengaruhi produktivitas salah satunya yakni manajemen. Selain itu teori menurut Ravianto, (2014) juga mengemukakan hal yang sama bahwa manajemen merupakan salah satu factor yang dapat mempengaruhi produktivitas pegawai maupun organisasi.

\section{KESIMPULAN DAN SARAN}

\section{Kesimpulan}

Penelitian ini bertujuan untuk mengetahui pengaruh manajemen kinerja (Penetapan Target Kinerja, Pelaksanaan Kinerja, Penilaian Kinerja, dan Evaluasi Kinerja) terhadap 
produktivitas pegawai di Bagian Pemerintahan Sekretariat Daerah Kota Batu, dan diperoleh beberapa kesimpulan sebagai berikut:

1. Berdasarkan hasil uji secara parsial disimpulkan bahwa:

a. Penetapan Target kinerja signifikan terhadap produktivitas pegawai di Bagian Pemerintahan Sekretariat Daerah Kota Batu. Dibuktikan dengan nilai signifikansi 0,049 kurang dari $(<)$ nilai signifikansi yang ditentukan yakni 0,05. Dengan demikian penelitian ini menolak H01 dan menerima Ha1. Hal ini menunjukkan semakin besar/ semakin matang proses penetapan target kinerja/perencanaan kinerja akan memberikan pengaruh pada peningkatan produktivitas pegawai.

b. Pelaksanaan kinerja secara parsial tidak berpengaruh signifikan terhadap produktivitas pegawai di Bagian Pemerintahan Sekretariat Daerah Kota Batu. Hal ini dibuktikan dengan nilai signifikansi sebesar 0,850 lebih besar (>) dari nilai signifikan yang ditentukan yaitu 0,05. Dengan demikian, penelitian ini menerima H02 dan menolak Ha2.

c. Penilaian kinerja secara parsial berpengaruh signifikan terhadap produktivitas pegawai di Bagian Pemerintahan Sekretariat Daerah Kota Batu. Hal ini dibuktikan dengan nilai signifikansi 0,00 kurang dari $(<)$ nilai signifikansi yang ditentukan yakni 0,05. Dengan demikian penelitian ini menolak H03 dan menerima Ha3.

d. Evaluasi kinerja secara parsial berpengaruh signifikan terhadap produktivitas pegawai di Bagian Pemerintahan Sekretariat Daerah Kota Batu. Hal ini dibuktikan dengan nilai signifikansi 0,015 kurang dari $(<)$ nilai signifikansi yang ditentukan yakni 0,05. Dengan demikian penelitian ini menolak H04 dan menerima Ha4.

e. Manajemen Kinerja (Penetapan Target Kinerja, Pelaksanaan Kinerja, Penilaian Kinerja, dan Evaluasi Kinerja) secara simultan berpengaruh signifikan secara bersama-sama terhadap produktivitas (Y), karena $\mathrm{F}$ hitung sebesar 15,738 dengan nilai sig. sebesar 0,000. Hal ini mengindikasikan bahwa semakin baik penerapan manajemen kinerja maka semakin baik pula produktivitas pegawai di Bagian Pemerintahan Sekretariat Daerah Kota Batu. 


\section{Saran}

1. Bagi instansi. Untuk meningkatkan produktivitas pegawai, pimpinan bekerjasama dengan pegawai harus mampu merencanakan target kinerja dengan baik dan terarah, melaksanakan tugas dan tanggung jawab sesuai rencana, melaksanakana penilaian kinerja sesuai apa yang dikerjakan, dan mengevaluasi setiap pekerjaan yang dilaksanakan sesuai periode yang ditentukan. Dengan begitu pegawai maupun pimpinan dapat mampu meningkatkan produktivitas sesuai dengan tuntutan kepala daerah maupun masyarakat.

2. Bagi peneliti selanjutnya. Hasil dari penelitian ini dapat digunakan sebagai bahan referensi guna melakukan penelitian tentang variabel-variabel yang mempengaruhi produktivitas pegawai dan sebaiknya peneliti yang akan datang menambah beberapa variabel lain yang dapat meningkatkan produktivitas pegawai.

\section{DAFTAR PUSTAKA}

Barthos, B. (2012). Manajemen Sumber Daya Manusia (Suatu Pendekatan Makro) (Edisi 1, C). Bumi Aksara.

Dunggio, M. (2013). Semangat Dan Disiplin Kerja Terhadap Produktivitas Kerja Karyawan Pada Pt. Jasa Raharja (Persero) Cabang Sulawesi Utara. Jurnal Riset Ekonomi, Manajemen, Bisnis Dan Akuntansi, 1(4), 523-533.

Ghozali, I. (2018). Aplikasi Analisis Multivariate dengan Program IBM SPSS 25 (Badan Pene).

Hayat. (2018). kebijakan publik (R. Tegar (ed.); 1st ed.). Instrans Publlishing.

Hayat (Universitas Islam Malang). (2014). Peningkatan Kualitas Sumber Daya Manusia Aparatur Pelayanan Publik dalam Kerangka Undang-Undang Nomor 5 Tahun 2014 tentang Aparatur Sipil Negara. Civil Servive: Jurnal Kebijakan Dan Manajemen PNS, 8(1), 31-44.

Nursam, N. (2017). Manajemen Kinerja. Kelola: Journal of Islamic Education Management, 2(2), 167-175. https://doi.org/10.24256/kelola.v2i2.438

Ravianto, J. (2014). Produktivitas dan Pengukuran. Binaman Aksara.

Salsabila Firdausy dan Ummu Nur Hanifah. (2018). PERMASALAHAN MANAJEMEN KINERJA DI INDONESIA DAN UPAYA KEMENTERIAN PANRB UNTUK MENGATASINYAitle. DEPUTI BIDANG REFORMASI BIROKRASI 


\section{AKUNTABILITAS APARATUR DAN PENGAWASAN.}

Sinungan, M. (2013). Produktivitas Apa Dan Bagaimana (Cetakan ke). Bumi Aksara.

Sugiyono. (2016). Metode Penelitian Kuantitatif, Kualitatif dan $R \& B$. PT. Alfabet.

Timur, P. J., \& Batu, P. W. (2018). Provinsi jawa timur peraturan walikota batu.

Wibowo. (2016). Manajemen Kinerja (kelima). rajawali pers.

Yusuf, B. (2015). Manajemen Sumber Daya Manusia di Lembaga Keuangan Syariah (M. N. R. AL Arif (ed.); cetakan ke). PT. Raja Grafindo Persada. 